\title{
Success of concrete and crab traps in facilitating Eastern oyster recruitment and reef development
}

\author{
Emma E Johnson ${ }^{1}$, Miles D Medina ${ }^{2}$, Ada C Bersoza Hernandez ${ }^{1}$, Gregory A Kusel ${ }^{1}$, Audrey N Batzer ${ }^{3}$, \\ Christine Angelini ${ }^{\text {Corresp. } 1}$ \\ 1 Department of Environmental Engineering Sciences, Engineering School of Sustainable Infrastructure and Environment, University of Florida, Gainesville, \\ FL, United States \\ 2 Department of Agricultural and Biological Engineering, University of Florida, Gainesville, FL, United States \\ ${ }^{3}$ School of Natural Resources and the Environment, University of Florida, Gainesville, FL, United States \\ Corresponding Author: Christine Angelini \\ Email address: c.angelini@ufl.edu
}

Background: Abundance of the commercially and ecologically important Eastern oyster, Crassostrea virginica, has declined across the US Eastern and Gulf coasts in recent decades, spurring substantial efforts to restore oyster reefs. These efforts are widely constrained by the availability, cost, and suitability of substrates to support oyster settlement and reef establishment. In particular, oyster shell is often the preferred substrate but is relatively scarce and increasingly expensive. Thus, there is a need for alternative oyster restoration materials that are cost-effective, abundant, and durable.

Methods: We tested the viability of two low-cost substrates-concrete and recycled blue crab (Callinectes sapidus) traps-in facilitating oyster recovery in a replicated 22-month field experiment at historically productive but now degraded intertidal oyster grounds on northwestern Florida's Nature Coast. Throughout the trial, we monitored areal oyster cover on each substrate; at the end of the trial, we measured the densities of oysters by size class (spat, juvenile, and market-size) and the biomass and volume of each reef.

Results: Oysters colonized the concrete structures more quickly than the crab traps, as evidenced by significantly higher oyster cover during the first year of the experiment. By the end of the experiment, the concrete structures hosted higher densities of spat and juveniles, while the density of market-size oysters was relatively low and similar between treatments. The open structure of the crab traps led to the development of larger-volume reefs, while oyster biomass per unit area was similar between treatments. In addition, substrates positioned at lower elevations (relative to mean sea level) supported higher oyster abundance, size, and biomass than those less frequently inundated at higher elevations.

Discussion: Together, these findings indicate that both concrete and crab traps are viable substrates for oyster reef restoration, especially when placed at lower intertidal elevations conducive to oyster settlement and reef development. 
1 Title: Success of concrete and crab traps in facilitating Eastern oyster recruitment and reef

2 development

3 Short Title: Restoring oysters with concrete and crab traps

4 Authors: Emma E. Johnson ${ }^{1}$, Miles D. Medina ${ }^{2 *}$, Ada C. Bersoza Hernandez ${ }^{1}$, Gregory A.

5 Kusel $^{1}$, Audrey N. Batzer ${ }^{3}$, Christine Angelini ${ }^{1 *}$

6 Author Affiliations and Emails:

$7 \quad{ }^{1}$ Department of Environmental Engineering Sciences, Engineering School of Sustainable

8 Infrastructure and Environment, University of Florida, Gainesville, FL, United States

$9 \quad{ }^{2}$ Department of Agricultural and Biological Engineering, University of Florida, Gainesville,

10 Florida, USA

$11{ }^{3}$ School of Natural Resources and the Environment, University of Florida, Gainesville, Florida, 12 USA

13 *Corresponding Author: Christine Angelini (c.angelini@ufl.edu) 


\section{Abstract}

16 Background: Abundance of the commercially and ecologically important Eastern oyster,

17 Crassostrea virginica, has declined across the US Eastern and Gulf coasts in recent decades,

18 spurring substantial efforts to restore oyster reefs. These efforts are widely constrained by the

19 availability, cost, and suitability of substrates to support oyster settlement and reef establishment.

20 In particular, oyster shell is often the preferred substrate but is relatively scarce and increasingly

21 expensive. Thus, there is a need for alternative oyster restoration materials that are cost-effective,

22 abundant, and durable.

23 Methods: We tested the viability of two low-cost substrates - concrete and recycled blue crab

24 (Callinectes sapidus) traps - in facilitating oyster recovery in a replicated 22-month field

25 experiment at historically productive but now degraded intertidal oyster grounds on northwestern

26 Florida's Nature Coast. Throughout the experiment, we monitored areal oyster cover on each

27 substrate; at the end of the trial, we measured the densities of oysters by size class (spat, juvenile, 28 and market-size) and the biomass and volume of each reef.

29 Results: Oysters colonized the concrete structures more quickly than the crab traps, as evidenced

30 by significantly higher oyster cover during the first year of the experiment. By the end of the

31 experiment, the concrete structures hosted higher densities of spat and juveniles, while the

32 density of market-size oysters was relatively low and similar between treatments. The open

33 structure of the crab traps enabled the development of larger-volume reefs, while oyster biomass

34 per unit area was similar between treatments. In addition, substrates positioned at lower

35 elevations relative to mean sea level supported higher oyster abundance, size, and biomass than

36 those less frequently inundated at higher elevations. 
37 Discussion: Together, these findings indicate that both concrete and crab traps are viable

38 substrates for oyster reef restoration, especially when placed at lower intertidal elevations

39 conducive to oyster settlement and reef development. 
40

41

42

43

44

45

46

47

48

49

50

51

52

53

54

55

56

57

58

59

60

61

62

\section{Introduction}

The Eastern oyster, Crassostrea virginica, (hereafter "oyster") is a commercially

important species that has been harvested for several centuries (Kirby, 2004; Lotze et al., 2006).

High, sustained demand for oysters has resulted in overexploitation of their reefs (Rothschild et

al., 1994; Jackson, 2001; Jordan \& Coakley, 2004), pressure that has acted with other stressorsclimate change (Wright et al., 2005; EOBRT 2007; Talmage \& Gobler, 2009; Levinton et al., 2011), disease (Kennedy \& Breisch, 1981; Berrigan, 1990; Jordan \& Coakley, 2004; Carranza,

Defeo \& Beck, 200; Powell et al., 2012), and coastal development and pollution (Mearns et al. 2010; Jackson, 2001; EOBRT, 2007; Bilkovic \& Roggero, 2008)—-to precipitously reduce their abundance. As a result, an estimated $85 \%$ of oyster reefs worldwide have been lost in the last 130 years (Beck et al., 2011). The dramatic and widespread loss of oyster reefs is concerning not only because of their importance as commercial fisheries (Peterson, Grabowski \& Powers, 2003; Rindone \& Eggleston, 2011; Pierson \& Eggleston, 2014) but also because of the estimated $\$ 550,000$ to $\$ 9,900,000 \mathrm{~km}^{-2} \mathrm{yr}^{-1}$ they provide in ecosystem services (Grabowski et al., 2012) including habitat for commercially and recreationally important fish and invertebrates, carbon sequestration, shoreline stabilization, and improvement of water quality through filter-feeding (Grabowski \& Peterson 2007).

57 To counteract oyster reef decline, over 1,700 oyster restoration projects covering more than $51.99 \mathrm{~km}^{2}$ of coastal habitat have been implemented across the US Atlantic and Gulf Coasts alone in the past half-century (Bersoza Hernandez et al., 2018). In areas where oyster larval delivery is not a limiting factor, reef establishment is often limited by the availability of stable substrate. Oyster-based substrates — including oyster shell bags, loose shell, spat-on-shell, and combinations of other materials with oyster shell - are the most common, accounting for $84 \%$ of 
63 the reef area constructed along the US Atlantic and Gulf Coasts (Bersoza Hernandez et al. 2018).

64 This preference for oyster-based substrates stems from studies showing that oyster larvae

65 preferentially settle on oyster shell in response to chemical cues emitted from conspecifics

66 (Bonar et al., 1990; Tamburri, Zimmer-Faust \& Tamplin, 1992; Turner et al., 1994). However,

67 reliance on oyster shell is problematic, because it is becoming increasingly scarce and expensive

68 (O’Beirn et al., 2000; Yozzo, Wilber \& Will, 2004). Furthermore, bioerosion due to boring

69 sponges and ocean acidification, as well as wave action, limit the life span and stability of oyster

70 shell in estuarine environments (Powell, Kraeuter \& Ashton-Alcox, 2006).

71 Given the impediments to using oyster shell, restoration practitioners and researchers

72 have been testing other substrates including concrete riprap, limestone, and granite (e.g., O'Beirn

73 et al., 2000; Nestlerode, Luckenbach \& O’Beirn, 2007). Dunn et al. (2014) evaluated the

74 performance of carbonate-based substrates (oyster shell and limestone marl) and non-carbonate-

75 based substrates (concrete and granite) in North Carolina and recorded similar oyster sizes and

76 growth rates one year after reef construction, suggesting that non-carbonate-based materials hold

77 promise for restoring subtidal reefs, especially in more saline areas where carbonate materials are

78 vulnerable to boring sponges. In the Gulf of Mexico, surveys of replicate rock-based and shell-

79 based restored reefs revealed that neither rock- nor shell-based restored reefs sustained oyster

80 densities comparable to those observed on natural reefs; but, of these two restoration materials,

81 rock supported greater oyster densities than shell across the region (La Peyre et al., 2014).

82 Similarly, Theuerkauf et al. (2014) compared unconsolidated oyster shell, oyster shell embedded

83 in concrete, and interlocking concrete oyster castles, and observed the highest live oyster

84 recruitment, biomass, and densities on the oyster castles. The oyster castles' superior

85 performance was attributed to their higher vertical relief, which prevented siltation and burial in 
86 the dynamic intertidal environment (Theuerkauf et al. 2014). Given the variable success of

87 alternative substrates, there remains a need to identify additional cost-effective, easy-to-deploy

88 materials and to quantify their performance in various environmental settings to inform future

89 oyster restoration efforts (Bersoza Hernandez et al. 2018).

90 In this study, we explore the potential of two relatively cost-effective, abundant, and

91 durable materials — concrete and wire crab traps — as restoration substrates for the Eastern oyster

92 (Crassostrea virginica). Concrete can be recycled from demolished infrastructure or freshly cast

93 in forms that vary in size and roughness, and it has been used in oyster restoration for several

94 decades (La Peyre et al., 2014; George et al., 2015). While the deployment of concrete as a

95 restoration substrate carries the risk of heavy metal leaching (Hiller et al., 1999; Hartwich \&

96 Vollpracht, 2017), metal content can be substantially reduced through pre-deployment

97 chemical elution (e.g., Höll, 1994). Wire traps designed for commercial and recreational blue

98 crab (Callinectes sapidus) fishing (hereafter, crab traps) are regularly collected by state agencies

99 via derelict trap removal programs. Abandoned traps are relatively abundant, durable, easy to

100 deploy, and cost-effective given their light weight and ability to be quickly stabilized with rebar

101 stakes (Kreutzer, 2014). Crab traps - which are sometimes dipped in concrete to enhance their

102 surface area, roughness, and durability — have been utilized for intertidal oyster reef restoration

103 extensively and successfully in South Carolina (Kingsley-Smith, 2012; Kreutzer, 2014). To our

104 knowledge, however, they have never been tested in the Gulf of Mexico where the tidal range is

105 narrower, waters are generally warmer, and oyster exposure to physical and biotic stressors-

106 such as hurricanes and predatory gastropods - differ. Both concrete and crab trap substrates may

107 offer viable alternative solutions for oyster restoration, but their relative efficacy in supporting

108 reef development has never been directly compared. These two substrates differ considerably in 
109 factors known to modulate oyster settlement, growth, and vulnerability to predators, including

110 surface area for settlement, chemical cues emitted from their surfaces, shaded surface areas, and

111 effects on water flow (e.g., Michener \& Kenny 1991, Turner et al. 1994, Bartol et al. 1999,

112 Soniat et al. 2004, Kuykendall et al. 2015).

113 To evaluate the relative performance of concrete and crab traps in oyster reef restoration,

114 we conducted a 22-month field experiment on degraded oyster bars in northwestern Florida. We

115 deployed five replicates of each structure type over a range of intertidal elevations to compare

116 the effects on temporal trends in oyster abundance, final densities of oysters by size class (spat,

117 juvenile, and market-size), and final oyster reef volume and biomass. We also monitored

118 barnacle densities due to the potential for ecological interactions between barnacles and oysters:

119 Through shell creation, lateral growth, and local effects on biofilm composition and formation,

120 barnacles may potentially facilitate or hinder oyster settlement (Osman, Whitlatch \& Zajac,

121 1989; Boudreaux, 2005).

122 We hypothesized that (1) oyster settlement would be higher on concrete structures than

123 crab traps, due to the larger surface area provided; (2) final reef volume and biomass would be

124 higher on crab traps at the experiment's conclusion, potentially due to the higher water flow

125 through the structures and, hence, food delivery to oysters; (3) oyster and barnacle densities

126 would be negatively correlated due to interspecific competition for space; and (4) both crab trap

127 and concrete structures placed lower in the intertidal would support higher oyster recruitment

128 and reef growth than those at higher elevations, due to shorter periods of inundation and food

129 availability.

130 Methods 
131

132

133

134

135

136

137

138

139

140

141

142

143

144

145

146

147

148

149

150

151

152

153

Site Location and Experimental Design

We deployed the field experiment in August 2015 on five offshore intertidal oyster bars located at Corrigan's Reef in Cedar Key, Florida (2909'50’N, 82 59’30’W) for a 22-month period ending in June 2017. These oyster bars, which were all located within a $400 \mathrm{~m}$ x $200 \mathrm{~m}$ area and spaced approximately 30 to $80 \mathrm{~m}$ apart, experience semidiurnal tides with a tidal range of -0.87 to $0.83 \mathrm{~m}$ above mean sea level (NOAA predicted tides for Cedar Key, FL:

https://tidesandcurrents.noaa.gov). In this region, live oysters are observed at elevations between -0.2 and $0.3 \mathrm{~m}$ above mean sea level, and our replicate structures were deployed between 0.1 and $0.25 \mathrm{~m}$ above mean sea level. The climate is subtropical with average air temperatures ranging from 13 to $28^{\circ} \mathrm{C}$ (National Data Buoy Center, 2015) and annual average precipitation of $117 \pm$ $2.35 \mathrm{~cm}$ per year (Western Regional Climate Center). In September 2016, 13 months into the experiment, Hurricane Hermine made landfall; however, none of the experimental structures was visibly damaged by the storm. Similarly, we did not observe scouring or sediment build-up around the structures, likely because Corrigan's Reef is located in a relatively protected bay and thus does not experience particularly high water velocities. Furthermore, the degraded oyster bars where our structures were placed are dominated by shell hash substrates that are more stable than sand or clay substrates characteristic of many other oyster restoration sites.

48 At each of the five oyster bars, we deployed one replicate of each substrate - a concrete reef and a crab trap — spaced about $4.5 \mathrm{~m}$ apart within the intertidal zone, where small clumps of live oysters were observed on the bar, indicating the potential for oyster settlement and growth (US Army Corps of Engineers permit SAJ-2015-01536(NW-JED)). We measured the elevation of each structure using a real-time kinematic GPS (Trimble Geo 7x, Trimble, Sunnyvale, California). Concrete structures were cast in the Structures Lab at the University of Florida 
154 (Gainesville, FL) and consisted of 12 notched, interlocking forms that assembled into a

155 rectangular structure. The modular design facilitated transportation and deployment, as each

156 piece weighed 7 to $20 \mathrm{~kg}$, and provided stability against moderate wave action. The concrete mix

157 design was standard, with an approximate ratio of 1:2:5:3 for water, cement, course aggregate,

158 and fine aggregate by weight (see Supplement for construction details). When assembled, the

159 structure exterior measured $42 \mathrm{~cm} \mathrm{H} \mathrm{x} 96 \mathrm{~cm} \mathrm{~L} \mathrm{x} 57 \mathrm{~cm} \mathrm{~W} \mathrm{(0.23} \mathrm{m³;} \mathrm{Fig.} \mathrm{1a).}$

160 The plastic-coated wire crab traps were collected from Florida Fish and Wildlife

161 Conservation Commission after their 2015 derelict trap clean-up, cleaned to remove any fouling

162 organisms, and secured to the substrate using $2 \mathrm{~m}$ rebar poles whose ends were bent into hooks.

163 Four crab traps were $42 \mathrm{~cm} \mathrm{H} \mathrm{x} 61 \mathrm{~cm} \mathrm{~L} \mathrm{x} 61 \mathrm{~cm} \mathrm{~W}\left(0.16 \mathrm{~m}^{3}\right.$; Fig. 1b), and the fifth was $26 \mathrm{~cm}$

$164 \mathrm{H} \mathrm{x} 120 \mathrm{~cm} \mathrm{~L} \mathrm{x} 61 \mathrm{~cm} \mathrm{~W}\left(0.19 \mathrm{~m}^{3}\right)$. The one trap with alternative dimensions was used in the

165 experiment at the request of restoration practitioners we work alongside, to evaluate whether this

166 trap type might also perform well in oyster restoration; however, because the mesh size was the

167 same for all traps (5 $\mathrm{cm} \times 2 \mathrm{~cm}$ mesh) and the majority of oysters settled on the bottom $25 \mathrm{~cm}$ of

168 the traps, we do not distinguish this trap from the others in our analyses. We closed all crab trap

169 openings using cable ties to prevent traps from capturing terrapins, blue crabs, and other larger

170 species; no dead animals were observed in the traps over the experiment's duration. In addition,

171 we recorded no visible deterioration of the crab traps; however, one concrete structure had one

172 piece knocked askew, likely by a boat, during the experiment.

\section{Data Collection}

174 Data were collected onsite on 20 September 2015 (1 month after deployment), 24 May

1752016 (9 months after deployment), 11 August 2016 (12 months after deployment), and 1 June

1762017 (22 months after deployment and immediately prior to harvesting). To assess oyster 
177 establishment on the structures, we monitored the percent cover of oysters by haphazardly

178 positioning replicate 15 by $15 \mathrm{~cm}$ frame quadrats on the seaward- and landward-facing sides of

179 each structure, between 5 and $15 \mathrm{~cm}$ from the sediment surface. We used six quadrats on each

180 side (seaward and landward) of each concrete structure, and four and two quadrats on each side

181 of the $0.16 \mathrm{~m}^{3}$ and $0.19 \mathrm{~m}^{3}$ crab traps, respectively. Within these same quadrats, we also

182 monitored the percent cover by barnacles to evaluate its impact on oyster recruitment and

183 settlement and to compare barnacle establishment rates between the two treatments. Other

184 potentially fouling species known to hinder oyster restoration success, such as sponges and

185 ascidians, were never observed on the restoration structures. In addition, predatory whelks and

186 conchs are common predators of oysters in the region but were not observed on the restoration

187 structures over the course of the experiment so were not monitored.

188 On the final observation date, we measured the dimensions of the oyster reef established

189 on each structure. Specifically, we took ten measurements of oyster reef height (i.e., the distance

190 between the benthos and the top of the highest live oyster) and eight measurements of each reef's

191 length and width at heights between 5 and $30 \mathrm{~cm}$ above the benthos. We estimated the percent

192 change in the volume of each reef by subtracting the initial structure volume (product of length,

193 width, and height) from the total volume of each reef (product of mean oyster reef length, width,

194 and height measurements) and dividing this difference by the initial structure volume. Structures

195 were then removed from the field, wrapped in tarps to protect the oysters established on them,

196 and transported to University of Florida's Coastal Engineering Lab. In the lab, we used 12

197 replicate 15 by $15 \mathrm{~cm}$ quadrats per structure to measure the percent cover of oysters and

198 barnacles and, within each, counted the number of spat $(<2.5 \mathrm{~cm})$, juvenile $(2.5-7.5 \mathrm{~cm})$, and

199 market-size oysters $(>7.5 \mathrm{~cm})$. We recorded densities of all three sizes classes because they 
200 provide unique demographic information about realized oyster recruitment, survival and

201 population development, and sex (i.e., oysters are sequential hermaphrodites that transition from

202 male to female as they get larger, Thompson et al. 1996). We also estimated oyster biomass per

203 unit area by removing, oven-drying to a constant weight, and weighing oysters collected from

204 three randomly selected 15 by $15 \mathrm{~cm}$ quadrats on each structure.

205 Data Analysis

206 Data were analyzed in R 3.4.3 using package 'mgcv' (Wood, 2011, 2016). To test for a

207 significant difference in the percent oyster cover between substrate types over time $(\alpha=0.05)$, we 208 specified a set of generalized linear mixed models (GLMMs) that assumed data were beta209 distributed (logit link function) and treated the observation date as a random effect (Breslow \& 210 Clayton, 1993). The full model included fixed effects for substrate type (concrete or crab trap), 211 substrate side (landward or seaward), reef elevation (m NGVD 29), percent barnacle cover, and 212 their interactions. Parameters were estimated using the restricted maximum likelihood (REML) 213 method. We compared the full model to reduced and null models using Akaike's information 214 criterion (AIC) and report results from the model achieving the lowest AIC value (Akaike, 215 1974). To test for a significant difference in the percent barnacle cover between treatments over 216 time, we used a similar GLMM approach, substituting barnacle cover for oyster cover as the 217 response variable and treating oyster cover as a fixed effect. The above GLMMs provide beta regression coefficients, which are the odds ratios of the mean response, holding all other variables constant (Ferrari \& Cribari-Neto, 2004). An odds ratio $P /(1-P)$ gives the probability, $P$, that an event occurs, divided by the probability that the event 221 does not occur. Thus, if an event is three times as likely to occur as to not occur, the probability 222 of the event occurring is $P=75 \%$ (odds $=0.75 / 0.25$ ). Each beta regression coefficient estimate $\hat{\beta}$ is 
223 the logarithm of the odds ratio for a regressor, and from $\hat{\beta}$ we estimate the probability of an event

224 occurring due to a unit increase in the regressor (or, in the case of a categorical variable, due to

225 switching from one factor level to another). That is, from $\beta=\ln \left(\frac{P}{1-P}\right)$ it follows that $P=\frac{e^{\beta}}{1+e^{\beta}}$.

226 For instance, if $\hat{\beta}=2$, the probability that the response occurs increases by an estimated $88 \%$

227 given a unit increase in the regressor.

228 To test for significant differences $(\alpha=0.05)$ in oyster abundance by size class (spat, 229 juvenile, market-size, and total), reef biomass, and reef volume between substrate types, we 230 specified generalized additive models (GAMs) that assumed the response variables exhibited a 231 Gaussian distribution and used the REML method (Hastie \& Tibshirani, 1990). The full models 232 for oyster density by size class included structure type, barnacle cover, elevation, and their 233 interactions as fixed factors; full models for oyster biomass and oyster reef volume included 234 structure type, elevation, and their interactions as fixed factors. For each hypothesis test, we 235 report results from the model achieving the lowest AIC value.

\section{Results}

238

239

240

241

242 243

244 barnacle cover had a significant negative effect on oyster cover. The observation date (random

245 effect) was significant, reflecting an increase in oyster cover on both substrate types over the 
246 experiment's duration (effective degrees of freedom $=1.94$, Chi-square=70.9, $p<0.001$, Fig. 1).

247 After detecting significant positive collinearity between the two numerical predictors in

248 the model — elevation and barnacle cover $(r=0.278, p<0.001)$ —we checked the robustness of the

249 above results against those from a model that excluded one of these predictors. Since oyster

250 cover was more highly correlated with barnacle cover $(r=-0.654, p<0.001)$ than with elevation

$251(r=-0.259, p<0.001)$, we excluded elevation as a fixed effect in the alternative model. The results

252 from this alternative model were consistent with those reported in Table 1.

253 Barnacle cover over time

254 The GLMM with the lowest AIC value indicated that substrate type, oyster cover,

255 elevation, and the substrate type-oyster cover interaction mediated barnacle cover over time (Fig.

2562 b, Table 1). Barnacle cover was $87 \%$ more likely to be higher on concrete structures than on

257 crab traps over time, and barnacle cover increased with elevation. As with oyster cover, barnacle

258 cover did not differ significantly between the landward and seaward sides of the structures. On

259 concrete structures, oyster cover had a significant negative effect on barnacle cover. The

260 observation date was not significant (effective degrees of freedom=1.11, Chi-square=2.73,

$261 p=0.086)$.

262 We detected significant negative collinearity between the two numerical predictors-

263 elevation and oyster cover $(r=-0.259, p<0.001)$ — and checked the robustness of the above results

264 against those from a simpler model that excluded elevation as a fixed effect, since barnacle cover

265 was more highly correlated with oyster cover than with elevation. The results from the

266 alternative model were consistent with those reported in Table 1.

267 Oyster abundance by size class

268 At the experiment's conclusion, spat, juvenile oyster, and total oyster abundances 
269 (individuals per $100 \mathrm{~cm}^{2}$ ) observed on concrete structures were 7.8, 2.4, and 3.0 times higher 270 than those observed on crab traps (Fig. 3, Table 2). Further, barnacle cover had a negative effect

271 on the final abundance of spat, juvenile oysters, and total oysters, but only on concrete structures.

272 The abundance of market-size oysters (i.e. those $>7.5 \mathrm{~cm}$ ) was relatively low (mean $\pm \mathrm{SE}$ :

$2730.27 \pm 0.06$ individuals per $100 \mathrm{~cm}^{2}$ across all structures) and did not differ between substrates.

274 Oyster reef volume

275 The percent change in oyster reef volume was significantly higher on crab traps

276 (mean \pm SE: $46.7 \pm 7.6 \%$ increase in volume) than on concrete structures (mean \pm SE: $22.4 \pm 7.5 \%$

277 increase in volume) and decreased with increasing elevation (Fig. 4a; Table 2).

278 Oyster reef biomass

279 Oyster biomass did not vary between substrate types or with elevation (Table 2). Mean

280 ( \pm SE) final biomass was $266.1( \pm 43.1) \mathrm{g}$ per $100 \mathrm{~cm}^{2}$ on concrete structures and $185.5( \pm 30.7) \mathrm{g}$

281 per $100 \mathrm{~cm}^{2}$ on crab traps (Fig. 4b).

282 Discussion

Our results reveal that concrete structures and crab traps facilitated oyster reef development

284

285

286

287

288

289

290

291

over the experiment's almost two-year period, suggesting that both substrates offer promising solutions for Eastern oyster restoration. In line with our first hypothesis, oysters colonized the concrete structures more quickly than the crab traps (Fig. 2a), and the more rapid establishment resulted in higher densities of oyster spat and juveniles on this material by the experiment's conclusion (Fig. 3). Oysters also established on crab traps and exhibited higher lateral growth on this substrate than on the concrete (Fig. 4a) as predicted by our second hypothesis, indicating that recycled blue crab traps can promote reef formation in micro-tidal, intertidal settings. Barnacles, which can compete with oysters for space, also mediated reef development, such that oysters 
292 established relatively quickly and achieved larger reef volumes at lower elevations where 293 barnacles were less abundant and where reefs remained inundated for longer, consistent with our 294 third and fourth hypotheses. Together with our observations that neither structure type deteriorated 295 over the experimental duration (and both survived a hurricane intact), these results suggest that 296 concrete and crab traps are durable, relatively low-cost materials that should be considered for

297 future restoration efforts. In sum, both experimental substrates successfully jumpstarted reef 298 formation, especially when deployed at elevations conducive to rapid oyster settlement and 299 growth.

In monitoring oyster cover over time, we discovered that the broad, flat surfaces of the concrete were particularly conducive to oyster settlement relative to the crab traps, whose mesh provided far less surface area for establishment (Figs. 1,2). The greater availability of settlement surface enabled the concrete to support high oyster recruitment through the 2015 reproductive season (August through October). It is important to note that these results may differ for concrete riprap or crushed concrete, which would have relatively less exposed surface than our interlocking, erect concrete structures. However, we also observed fairly rapid increases in oyster cover on the crab traps during the second summer, likely because those oysters engineered and expanded the available surface area and emitted chemical cues to conspecifics. As a result, there was a near convergence in oyster cover between treatments by the experiment's end (Fig. 2a) and both materials achieved oyster spat, juvenile and adult densities similar or even higher to those reported

311 for concrete and oyster shell-based reefs of a similar age in Texas (Graham et al., 2017) and in

312 North Carolina (Theuerkauf et al., 2015). Importantly, these dynamics suggest that materials with

313 high surface areas and ample availability of shaded surfaces - like our interlocking concrete block 314 structures or widely-used oyster shell bags - are not necessarily a prerequisite for successful oyster 
315 restoration. Instead, mesh-like materials (e.g., crab traps)—which are typically lighter in weight 316 and thus cheaper to construct, transport, and install — can be viable restoration substrates as long 317 as they support some initial oyster settlement. In addition to their low cost, crab traps are durable 318 and can last 3-7 years in intertidal environments, depending on whether the wire is bare or vinyl319 coated (Benjamin Stone and Nancy Hadley, personal communication). Furthermore, a South 320 Carolina study found that dipping crab traps in concrete resulted in higher recruitment rates 321 compared to unaltered crab traps, possibly because the concrete creates a textured surface that 322 increases surface area and because calcium carbonate in the concrete may mimic oysters' natural 323 chemical cues (Kreutzer, 2014). Before their widespread use in restoration is recommended, 324 additional studies are needed to evaluate the relative performance of bare, vinyl-, and concrete325 coated crab traps in different hydrodynamic, oyster larval delivery, and spatial (e.g. intertidal vs. 326 subtidal) contexts.

It is important to note that we only present coverage data from the structures' exterior 328 surfaces, due to the difficulty in quantifying interior oyster and barnacle cover without destroying the structures and the organisms settled upon them. However, we observed significant oyster colonization on the mesh that bisected the interior of the crab traps as well as on the broad interior surfaces of the concrete structures. Inclusion of data from these interior surfaces would certainly alter the inferences drawn from this work to some extent; however, we anticipate that the main 333 factors influencing oyster and barnacle cover — substrate type and elevation — would not change 334 with these interior data. That is, the trends reflected in Fig. 2 are consistent with our observations 335 of the structure interiors: We observed rapid oyster colonization of the interior surfaces of the 336 concrete and more gradual, but substantial, oyster colonization of the interior mesh of the crab traps (CA, ANB and GAK, personal observations). 

not market-size oysters, on concrete structures relative to crab traps (Fig. 3). We attribute this difference to earlier and quicker colonization of concrete structures, which likely resulted from the concrete's greater surface area, conspecific feedbacks (i.e., additional surface area and positive oysters cooler or increase their vulnerability to heat depending on the duration the structures are inundated by the tides). In general, the sustained, high levels of oyster settlement and growth on both structures indicate that oyster larval loads were quite high during the experiment and are consistent with long-standing knowledge that oysters settle gregariously on conspecifics (e.g. 347 Crisp, 1967; O’Beirn et al., 2000). These results also suggest that there are positive, density348 dependent feedbacks whereby strong recruitment and growth in one year can promote and sustain 349 higher oyster densities in subsequent years, as has been documented in longer-term datasets (e.g. Powell et al., 2009) and proposed in a recent modeling study (Moore, Puckett \& Schreiber, 2018). Interestingly, despite differences in oyster cover and in spat and juvenile densities, marketsize oysters were relatively rare, with similar densities between substrates. This finding coincides with prior work documenting that oysters in this region typically reach market size within two years (e.g., Wilbur, 1992) and that density-dependent growth and/or predation by oyster toadfish, blue crabs, oyster drills and other common oyster predators on the concrete structures may have prevented more individuals from reaching market size and transitioning to females. Furthermore, 357 pathogens that have particularly strong effects on larger individuals and during drier years, such 358 as Perkinsus marinus (La Peyre et al. 2003, Soniat et al. 2006), may have contributed to mortality 359 in market-size oysters. We anticipate that a longer experiment would have shown a larger 360 proportion of market-size females than observed. 

volume was greater on crab traps than on concrete, while oyster biomass per unit area was the same (Fig. 4). These results reveal that the oyster reefs proliferating on each structure type differed

364 365 366 367 368 369

382 substrates deployed.

in their morphological structure: The concrete-based reefs were shallow and compact, while the reefs that formed on the crab traps were sparser but deeper. We suspect these differences in reef morphology arose due their differential surface areas and effects on water flow. Specifically, while the larger surface area of the concrete enabled these structures to become blanketed in oyster spat during the first year, subsequent growth may have been reduced by the propensity of the wide, flat concrete faces to direct flows around, rather than through, the structure (dynamics that would differ for concrete riprap or crushed concrete). This, in turn, may have hampered delivery of food to settled oysters and thus slowed the reef's ability to extend laterally (Malouf \& Breese, 1977; Grizzle, Langan \& Howell, 1992). In contrast, although fewer oysters could settle on the mesh of the crab traps, those individuals that were able to establish may have grown more quickly due to less restricted water flow and food delivery, thus creating reefs with higher vertical relief and higher-quality predation refuges for spat (Soniat et al., 2004). In addition to these physical factors, it is possible that oysters experienced different levels and types of predation on the two substrates such as that imposed by oyster drills and blue crabs, and thus top-down control may have contributed to driving the morphological differences in reef structure. Over longer timescales and in subtidal environments where crab traps have-to our knowledge-never been utilized for restoration, these differences in reef structure may influence the relative 'success' of each substrate in promoting the growth and expansion of living oyster reefs beyond the initial footprint of the 
384 lower elevations relative to mean sea level (Table 1, 2). This finding coincides with results from 385 several other oyster restoration studies (Lenihan, Peterson \& Allen, 1998; Bartol, Mann \& 386 Luckenbach, 1999) and natural reefs (Powell et al., 2009) documenting pronounced variation in 387 oyster settlement, mortality, and growth rates with elevation. Consistent with conclusions drawn 388 from this earlier work, our results highlight the value of investing in preliminary studies to identify 389 optimal elevational zones prior to deployment of restoration material. Such baseline data, which

390 is needed for both intertidal and subtidal oyster restoration, will likely be essential to ensuring 391 project success and positive returns on investment with regards to oyster growth and ecosystem 392 service provisioning (Bersoza Hernández et al., 2018).

\section{Conclusions}

Our results contribute to an expanding body of work in environmental engineering and sustainable materials design exploring how waste materials from one sector can be repurposed and recycled for environmental benefit (e.g., Fiskel, 2006). Although our concrete structures were newly cast for this project, concrete is a common waste product with strong potential for oyster reef restoration, as long as the concrete is adequately cleaned and decontaminated. Similarly, abandoned crab traps — which can obstruct boat traffic and continue to trap and kill organisms - can provide a valuable substrate to facilitate the establishment of new living reefs

401 (Kreutzer, 2014). Repurposing these waste materials as restoration substrates can reduce burdens 402 on waste facilities, reduce costs associated with restoration, and ultimately restore ecosystem 403 services provided by oyster reefs, including carbon sequestration, water quality enhancement, 404 and habitat for ecologically and commercially important faunal communities (Grabowski et al., 
405 2012). More generally, our work demonstrates the viability of alternatives to oyster shell

406 substrates for jumpstarting and sustaining oyster recovery in the Gulf of Mexico.

407 Acknowledgments

408 The authors thank Chris Ferraro, Enrique Garcia, and Taylor Humbarger at the University

409 of Florida Structures Lab for their help in constructing the molds and casting the concrete

410 structures. We also thank Jerry and Laura Adams for sharing their expertise and shuttling us to

411 Corrigan's Reef to collect data.

412 


\section{Literature Cited}

414 Akaike H. 1974. A new look at the statistical model identification. IEEE Transactions on 415 Automatic Control 19:716-723.

416 Bartol IK, Mann R, Luckenbach M. 1999. Growth and mortality of oysters (Crassostrea 417 virginica) on constructed intertidal reefs: Effects of tidal height and substrate level. Journal 418 of Experimental Marine Biology and Ecology 237:157-184. DOI: 10.1016/S0022$419 \quad 0981(98) 00175-0$.

420

421

422

423

424

425

426

427

428

429

430

431

432

433

434

435

Beck MW, Brumbaugh RD, Airoldi L, Carranza A, Coen LD, Crawford C, Defeo O, Edgar GJ, Hancock B, Kay MC, Lenihan HS, Luckenbach MW, Toropova CL, Zhang G, Guo X. 2011. Oyster reefs at risk and recommendations for conservation, restoration, and management. BioScience 61:107-116. DOI: 10.1525/bio.2011.61.2.5.

Berrigan ME. 1990. Biological and economical assessment of an oyster resource development project in Apalachicola Bay, Florida. Journal of Shellfish Research 9:149-158.

Bersoza Hernández A, Brumbaugh R, Frederick P, Grizzle R, Luckenbach MW, Peterson CH, Angelini C. 2018. Restoring the Eastern oyster: How much progress has been made in 53 years of effort? Frontiers in Ecology and the Environment. DOI:10/1002/fee.1935

Bilkovic DM, Roggero MM. 2008. Effects of coastal development on nearshore estuarine nekton communities. Marine Ecology Progress Series 358:27-39.

Bonar DB, Coon SL, Walch M, Weiner RM, Fitt W. 1990. Control of oyster settlement and metamorphosis by endogenous and exogenous chemical cues. Bulletin of Marine Science 46:484-498. DOI: 10.1007/s12237-010-9338-6.

Boudreaux ML. 2005. Native and Invasive Competitors of the Eastern Oyster Crassostrea Virginica in Mosquito Lagoon, Florida. Masters Thesis. University of Central Florida. 532. 
http://stars.library.ucf.edu/etd/532

437 Breslow NE, Clayton DG. 1993. Approximate inference in generalized linear mixed models.

$438 \quad$ Journal of the American Statistical Association 88:9-25.

439 Brown, L.A., Furlong, J.N., Brown, K.M., La Peyre, M.K. 2014. Oyster reef restoration in the

440 northern gulf of Mexico: Effect of artificial substrate and age on nekton and benthic

441 macroinvertebrate assemblage use. Restoration Ecology 22:214-222. DOI:

$442 \quad$ https://doi.org/10.1111/rec.12071

443 Carranza A, Defeo O, Beck M. 2008. Diversity, conservation status and threats to native oysters

444 (Ostreidae) around the Atlantic and Caribbean coasts of South America. Aquatic

445 Conservation: Marine and Freshwater Ecosystems DOI: 10.1002/aqc.993.

446 Coen LD. 2011. Managing Oysters in South Carolina: A Five Year Program to Enhance/Restore

447 Shellfish Stocks and Reef Habitats Through Shell Planting and Technology Improvements.

448 Charleston, SC. Marine Resources Center, SCDNR. https://www.loc.gov/item/2014472847/

449 Crisp DJ. 1967. Chemical factors inducing settlement in Crassostrea virginica (Gmelin). Journal $450 \quad$ of Animal Ecology 36:329-335.

451 Dunn RP, Eggleston DB, Lindquist N. 2014. Effects of substrate type on demographic rates of 452 Eastern oyster (Crassostrea virginica). Journal of Shellfish Research 33(1): 177-185.

453 Easter Oyster Biological Review Team (EOBRT). 2007. Status review of the Eastern Oyster

454 (Crassostrea virginica). Report to the National Marine Fisheries Service, Northeast

455 Regional Offic. NOAA Technical Memo. NMFS F/SPO-88.

456 Ferrari S, Cribari-Neto F. 2004. Beta regression for modelling rates and proportions. Journal of

$457 \quad$ Applied Statistics 31:799-815.

458 Fiskel J. 2006. A framework for sustainable materials management. JOM 58: 15-22. 
459 Garland HG, Kimbro DL. 2015. Drought increases consumer pressure on oyster reefs in Florida, $460 \quad$ USA. PLoS ONE 10:19. DOI: 10.1371/journal.pone.0125095.

461 George LM, De Santiago K, Palmer TA, Beseres Pollack J. 2015. Oyster reef restoration: effect 462 of alternative substrates on oyster recruitment and nekton habitat use. Journal of Coastal 463 Conservation 19. DOI: 10.1007/s11852-014-0351-y.

464 Grabowski JH, Brumbaugh RD, Conrad RF, Keeler AG, Opaluch JJ, Peterson CH, Piehler MF, 465 Powers SP, Smyth AR. 2012. Economic valuation of ecosystem services provided by oyster 466 reefs. BioScience 62:900-909. DOI: 10.1525/bio.2012.62.10.10.

467 Grabowski JH, Peterson CH. 2007. Restoring oyster reefs to recover ecosystem services. In: 468 Ecosystem Engineers: Plants to Protists. 281-298.

469 Graham PM., Palmer TA., Pollack JB. 2017. Oyster reef restoration: substrate suitability may 470 depend on specific restoration goals. Restoration Ecology 25: 459-470. DOI:

$471 \quad 10.1111 /$ rec.12449.

472 Grizzle RE., Langan R., Howell WH. 1992. Growth responses of suspension-feeding bivalve 473 molluscs to changes in water flow: differences between siphonate and nonsiphonate taxa. $474 \quad$ Journal of Experimental Marine Biology and Ecology 162:213-228.

475 Hartwich, P. \& Vollpracht, A. 2017. Influence of leachate composition on the leaching behaviour 476 of concrete. Cement and Concrete Research, 100: 423-434. DOI:

$477 \quad$ 10.1016/j.cemconres.2017.07.002

478 Hastie TJ, Tibshirani RJ. 1990. Monographs on Statistics and Applied Probabilities: Generalized 479 additive models. Chapman \& Hall/CRC Press.

480 Hillier, S.R., Sangha, C.M., Plunkett, B.A., \& Walden, P.J. 1999. Long-term leaching of toxic 481 trace metals from Portland cement concrete. Cement and Concrete Research, 29(4): 515- 
482

483

484

485

486

487

488

489

490

491

492

493

494

495

496

497

498

499

500

501

502 503

504

521. DOI: $10.1016 / \mathrm{S} 0008-8846(98) 00200-2$

Höll, W.H. 1994. Leaching of heavy metals from contaminated concrete rubbish material. In: Hydrometallurgy '94. Springer, Dordrecht. DOI: 10.1007/978-94-011-1214-7_67

Jackson JBC. 2001. What was natural in the coastal oceans? Proceedings of the National Academy of Sciences 98:5411-5418. DOI: 10.1073/pnas.091092898.

Jordan SJ, Coakley JM. 2004. Long-term projections of Eastern oyster populations under various management scenarios. Journal of Shellfish Research 23:63-73.

Kennedy VS, Breisch LL. 1981. Maryland's oysters: research and management. Maryland Sea Grant, University of Maryland College Park, Maryland.

Kimbro DL, White JW, Tillotson H, Cox N, Christopher M, Stokes-Cawley O, Yuan S, Pusack TJ, Stallings CD. 2017. Local and regional stressors interact to drive a salinization-induced outbreak of predators on oyster reefs. Ecosphere. DOI: 10.1002/ecs2.1992.

Kingsley-Smith, P.R., Joyce, R.E., Arnott, S.A., Roumillat, W.A., McDonough, C.J., Reichert, M.J.M. 2012. Habitat use of intertidal Eastern oyster (Crassostrea virginica) reefs by nekton in South Carolina Estuaries. Journal of Shellfish Research 31: 1009-1021.

Kirby MX. 2004. Fishing down the coast: historical expansion and collapse of oyster fisheries along continental margins. Proceedings of the National Academy of Sciences of the United States of America 101:13096-9. DOI: 10.1073/pnas.0405150101.

Kreutzer AD. 2014. Role of crab traps in oyster restoration. Masters thesis. College of Charleston, Charleston, SC. http://hdl.handle.net/123456789/3026.

Kuykendall KM, Moreno P, Powell EN, Soniat TM, Colley S, Mann R, Munroe DM. 2015. The exposed surface area to volume ration: is shell more efficient than limestone in promoting oyster recruitment? Journal of Shellfish Research 34(2): 217-225. DOI: 
506

507

508

509

510

511

512

513

514

515

516

517

518

519

520

521

522

523

524

525

526

La Peyre M, Furlong J, Brown LA, Piazza BP, Brown K. 2014. Oyster reef restoration in the northern Gulf of Mexico: Extent, methods and outcomes. Ocean and Coastal Management 89:20-28. DOI: 10.1016/j.ocecoaman.2013.12.002.

La Peyre MK, Nickens AD, Volety AK, Tolley GS, La Peyre JF. 2003. Environmental significance of freshets in reducing Perkensis marinus infection in eastern oysters Crassostrea virginica: potential management applications. Marine Ecology Progress Series 248: $165-176$.

Lenihan HS, Peterson CH, Allen JM. 1998. Does flow speed also have a direct effect on growth of active suspension feeders: An experimental test on oysters. Limnology and Oceanography 41:1359-1366.

Levinton J, Doall M, Ralston D, Starke A, Allam B. 2011. Climate change, precipitation and impacts on an estuarine refuge from disease. PLoS ONE 6. DOI: 10.1371/journal.pone.0018849.

Lotze HK, Lenihan HS, Bourque BJ, Bradbury RH, Cooke RG, Kay MC, Kidwell SM, Kirby MX, Peterson CH, Jackson JBC. 2006. Depletion, degradation, and recovery potential of estuaries and coastal seas. Science 312:1806-1809.

Malouf RE, Breese WP. 1977. Seasonal changes in the effects of temperature and water flow rate on the growth of juvenile Pacific oysters, Crassostrea gigas (Thunberg). Aquaculture 12:113.

Mearns AJ, Reish DJ, Oshida PS, Ginn T, Rempel-Hester MA. Effects of pollution on marine organisms. Water Environment Research 83. DOI: 10.2175/106143011X13075599870171.

527 Menzel RW, Hulings NC, Hathaway RR. 1966. Oyster abundance in Apalachicola Bay, Florida 
528 in relation to biotic associations influenced by salinity and other factors. Gulf Research

529 Reports 2:73-96. DOI: 10.18785/grr.0202.01.

530 Michener WK, Kenny PD. 1991. Spatial and temporal patterns of Crassostrea virginica

531 (Gmelin) recruitment: relationship to scale and substratum. Journal of Experimental Marine

532 Biology and Ecology 154(1): 97-121. DOI: 10.1016/0022-0981(91)90077-A.

533 Moore JL, Puckett BJ, Schreiber SJ. 2018. Restoration of Eastern oyster populations with

534 positive density dependence. Ecological Applications 28:897-909.

535 National Data Buoy Center. 2015.Station CDRF1 - Climatic summary plots for air temperature.

536 Available at http://www.ndbc.noaa.gov/view_climplot.php?station=cdrf1\&meas=at

537 National Oceanographic and Atmospheric Administration (NOAA). 2010. Mean sea level trend,

538 station 8727520, Cedar Key, Florida. Available at http://co-ops.nos.noaa.gov/

539 sltrends/sltrends_station.shtml?stnid=8727520

540 Nestlerode JA, Luckenbach MW, O’Beirn FX. 2007. Settlement and survival of the oyster

541 Crassostrea virginica on created oyster reef habitats in Chesapeake Bay. Restoration

542 Ecology 15:273-283. DOI: 10.1111/j.1526-100X.2007.00210.x.

543 O’Beirn FX, Luckenbach MW, Nestlerode JA, Coates GM. 2000. Toward design criteria in

544 constructed oyster reefs: Oyster recruitment as a function of substrate type and tidal height.

$545 \quad$ Journal of Shellfish Research 19:387-395.

546 Osman R, Whitlatch R, Zajac R. 1989. Effects of resident species on recruitment into a

547 community larval settlement versus post-settlement mortality in the oyster Crassostrea

$548 \quad$ virginica. Marine Ecology Progress Series 54:61-73. DOI: 10.3354/meps054061.

549 Peterson CH, Grabowski JH, Powers SP. 2003. Estimated enhancement of fish production

550 resulting from restoring oyster reef habitat: Quantitative valuation. Marine Ecology 
Progress Series 264:249-264. DOI: 10.3354/meps264249.

552 Pierson KJ, Eggleston DB. 2014. Response of estuarine fish to large-scale oyster reef restoration.

553 Transactions of the American Fisheries Society 143:273-288. DOI:

$554 \quad 10.1080 / 00028487.2013 .847863$.

555 Powell EN, Klinck JM, Ashton-Alcox K, Hofmann EE, Morson J. 2012. The rise and fall of

556 Crassostrea virginica oyster reefs: The role of disease and fishing in their demise and a

557 vignette on their management. Journal of Marine Research 70:505-558. DOI:

$558 \quad 10.1357 / 002224012802851878$.

559 Powell EN, Klinck JM, Ashton-Alcox KA, Kraeuter JN. 2009. Multiple stable reference points

560 in oyster populations: biological relationships for the Eastern oyster (Crassostrea virginica)

561 in Delaware Bay. Fishery Bulletin 107:109-132.

562 Powell EN, Kraeuter JN, Ashton-Alcox KA. 2006. How long does oyster shell last on an oyster 563 reef? Estuarine, Coastal and Shelf Science 69:531-542. DOI: 10.1016/j.ecss.2006.05.014.

564 Rindone RR, Eggleston DB. 2011. Predator-prey dynamics between recently established stone

565 crabs (Menippe spp.) and oyster prey (Crassostrea virginica). Journal of Experimental

566 Marine Biology and Ecology 407:216-225. DOI: 10.1016/j.jembe.2011.06.018.

567 Rothschild BJ, Ault JS, Goulletquer P, Heral M. 1994. Decline of the Chesapeake Bay oyster

568 population: A century of habitat destruction and overfishing. Marine Ecology Progress

$569 \quad$ Series 111:29-40. DOI: 10.3354/meps111029.

570 Scyphers SB, Powers SP, Heck KL, Byron D. 2011. Oyster reefs as natural breakwaters mitigate

571 shoreline loss and facilitate fisheries. PLOS ONE 6. DOI: 10.1371/journal.pone.0022396.

572 Seavey JR, Pine WE, Frederick P, Sturmer L, Berrigan M. 2011. Decadal changes in oyster reefs 573 in the Big Bend of Florida's Gulf Coast. Ecosphere 2:1-14. DOI:10.1890/ES11-00205.1. 
574 Soniat, T.M., Finelli, C.M., Ruiz, J.T., 2004. Vertical structure and predator refuge mediate 575 oyster reef development and community dynamics. J. Exp. Mar. Bio. Ecol. 310, 163-182. $576 \quad$ https://doi.org/10.1016/j.jembe.2004.04.007

577 Soniat TM, Klinck JM, Powell EN, Hofmann EE. 2006. Understanding the success and failure of 578 oyster populations: Climatic cylces and Perkensis marinus. Journal of Shellfish Research 579 25: 83-93. DOI: 10.2983/0730-8000(2006)25[83:UTSAFO]2.0.CO;2.

580 Talmage SC, Gobler CJ. 2009. The effects of elevated carbon dioxide concentrations on the 581 metamorphosis, size, and survival of larval hard clams (Mercenaria mercenaria), bay 582 scallops (Argopecten irradians), and Eastern oysters (Crassostrea virginica). Limnology 583 and Oceanography 54:2072-2080. DOI: 10.4319/lo.2009.54.6.2072.

584 Tamburri MN, Zimmer-Faust RK, Tamplin ML. 1992. Natural sources and properties of 585 chemical inducers mediating settlement of oyster larvae: a re-examination. Biological $586 \quad$ Bulletin 183:327-338. DOI: 10.2307/1542218.

587 Theuerkauf SJ, Burke RP, Lipcius RN. 2015. Settlement, growth and survival of Eastern oysters 588 on alternative reef substrates. Journal of Shellfish Research 34(2): 241-250. DOI: $589 \quad 10.2983 / 35.035 .0205$.

590 Thompson, RJ, Newell REI, Kennedy VS, Mann R. 1996. Reproductive processes and early 591 development. In: Kennedy, V.S., R.I.E. Newell, and A.F. Eble (eds.) pp. 335-370. The 592 Eastern Oyster Crassostrea virginica. Maryland Sea Grant College, University of Maryland 593 System, College Park, MD.

594 Turner EJ, Zimmer-Faust RK, Palmer MA, Luckenbach M, Pentcheff ND. 1994. Settlement of 595 oyster (Crassostrea virginica) larvae: effects of water flow and a water- soluble chemical $596 \quad$ cue. Limnology and Oceanography 39:1579-1593.DOI: 10.44319/lo.1994.39.7.1579. 
597 Western Regional Climate Center. Period of Record Monthly Climate Summary. Available at $598 \quad$ https://wrcc.dri.edu/cgi-bin/cliMAIN.pl?fl1432.

599 Wilber DH. 1992. Associations between freshwater inflows and oyster productivity in $600 \quad$ Apalachicola Bay, Florida. Estuarine, Coastal and Shelf Science 35:179-190.

601 Wood SN. 2011. Fast stable restricted maximum likelihood and marginal likelihood estimation 602 of semiparametric generalized linear models. Journal of the Royal Statistical Society B $603 \quad 73: 3-36$.

604 Wood SN. 2016. Just another Gibbs additive modeller: interfacing JAGS and mgcv. Journal of $605 \quad$ Statistical Software.

606 Wright EE, Hine AC, Goodbred SL, Locker SD. 2005. The effect of sea-level and climate 607 change on the development of a mixed Siliciclastic-Carbonate, Deltaic coastline: Suwannee 608 River. Journal of Sedimentary Research 75:621-635. DOI: 10.2110/jsr.2005.051.

609 Yozzo DJ, Wilber P, Will RJ. 2004. Beneficial use of dredged material for habitat creation, 610 enhancement, and restoration in New York-New Jersey Harbor. Journal of Environmental 611 Management 73:39-52. DOI: 10.1016/j.jenvman.2004.05.008.

612 Zu Ermgassen PSE, Spalding MD, Blake B, Coen LD, Dumbauld B, Geiger S, Grabowski JH, 613 Grizzle R, Luckenbach M, Mcgraw K, Rodney W, Ruesink JL, Powers SP, Brumbaugh R. 614 2012. Historical ecology with real numbers: past and present extent and biomass of an 615 imperilled estuarine habitat. Proceeding of the Royal Society B. DOI:

$616 \quad 10.1098 /$ rspb.2012.0313. 


\section{Figure 1}

Photos of concrete and crab trap treatments at the start and end of the experiment Interlocking concrete structures (a) and crab traps (b) at the start of the experiment and 17 months later (c, d).
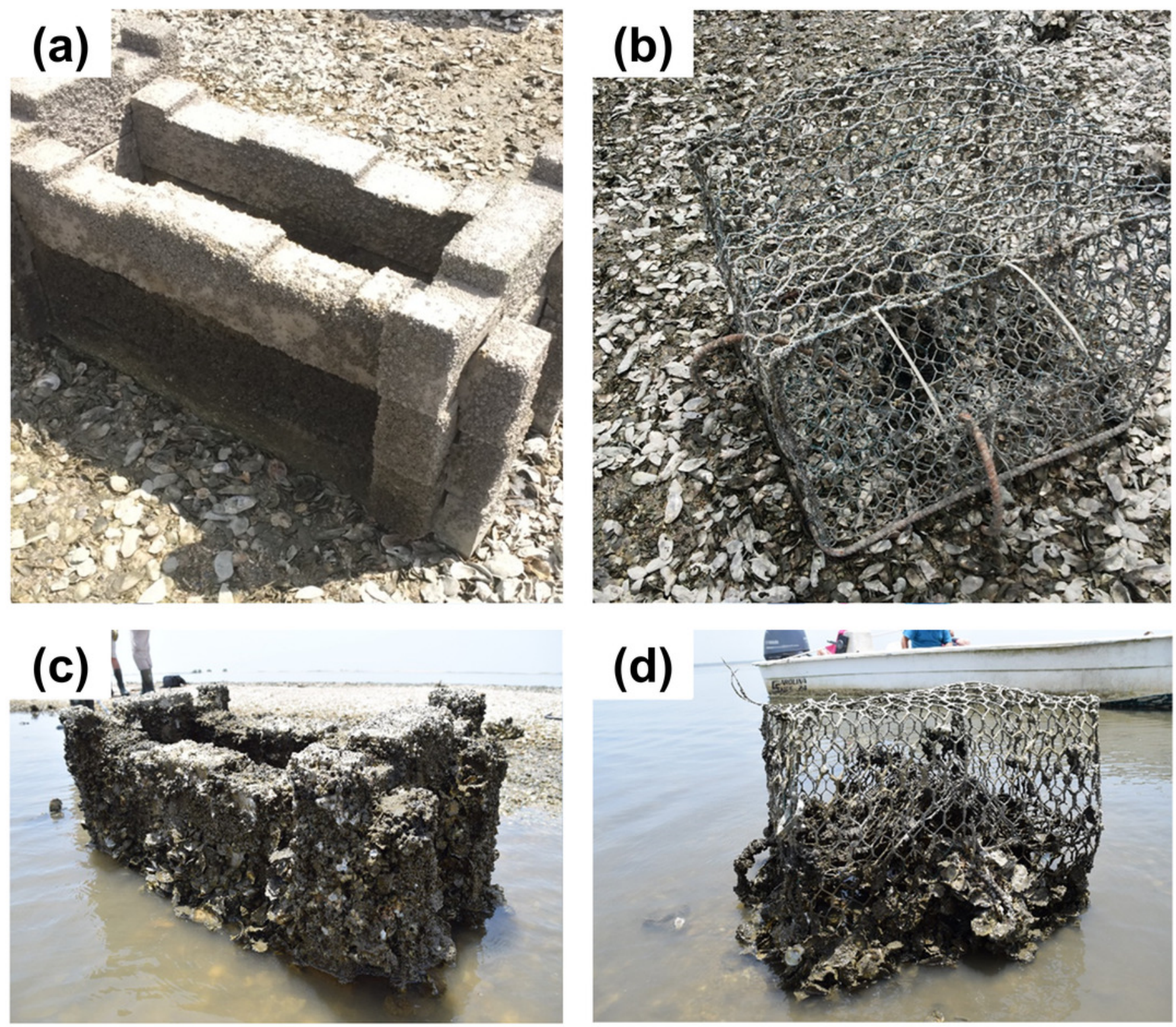


\section{Figure 2}

Changes in oyster cover and barnacle cover over time.

Changes in oyster percent cover (a) and in barnacle percent cover on concrete (open circles) and crab traps (solid squares) over the course of the experiment. 
(a)

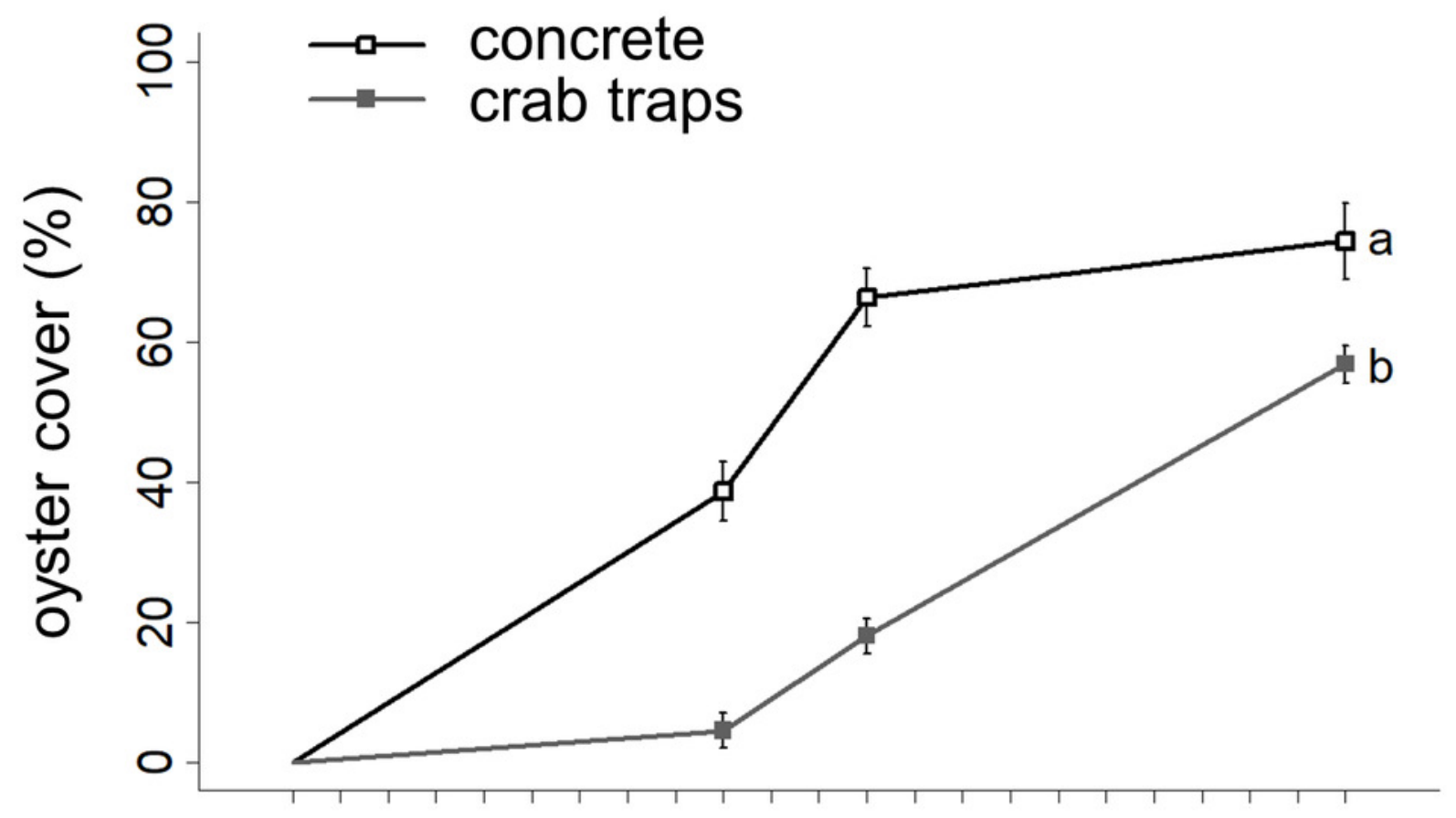

(b)




Figure 3

Oyster density recorded at the end of the experiment.

The number of individual spat, juvenile oysters, market sized oysters and the total number of oysters recorded within 10 by $10 \mathrm{~cm}$ square quadrate at the end of the experiment.

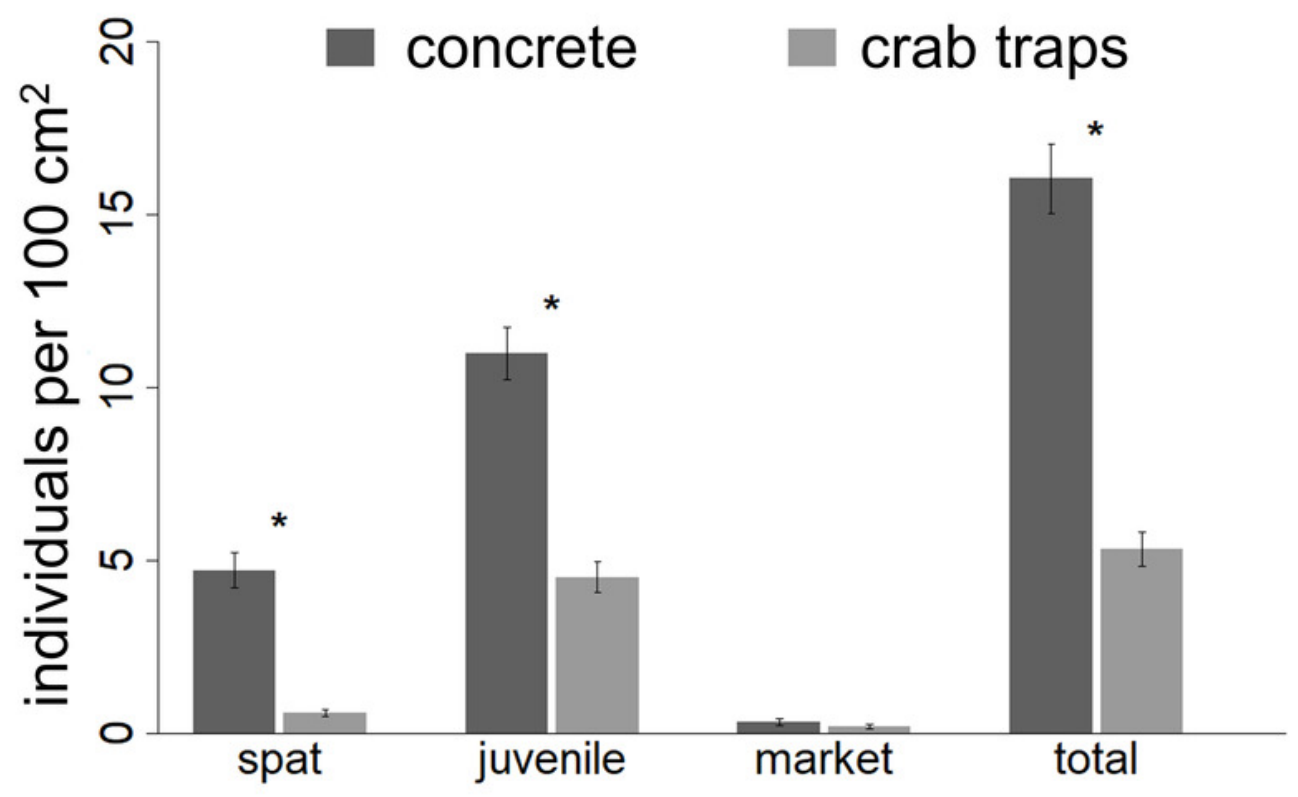


Figure 4

Change in oyster reef volume and final oyster biomass on restoration structures.

The percent change in oyster reef volume recorded on the concrete and crab trap structures

(a) and the final oyster biomass recorded in a 10 by $10 \mathrm{~cm}$ quadrat (b) at the end of the experiment.

(a)



(b)

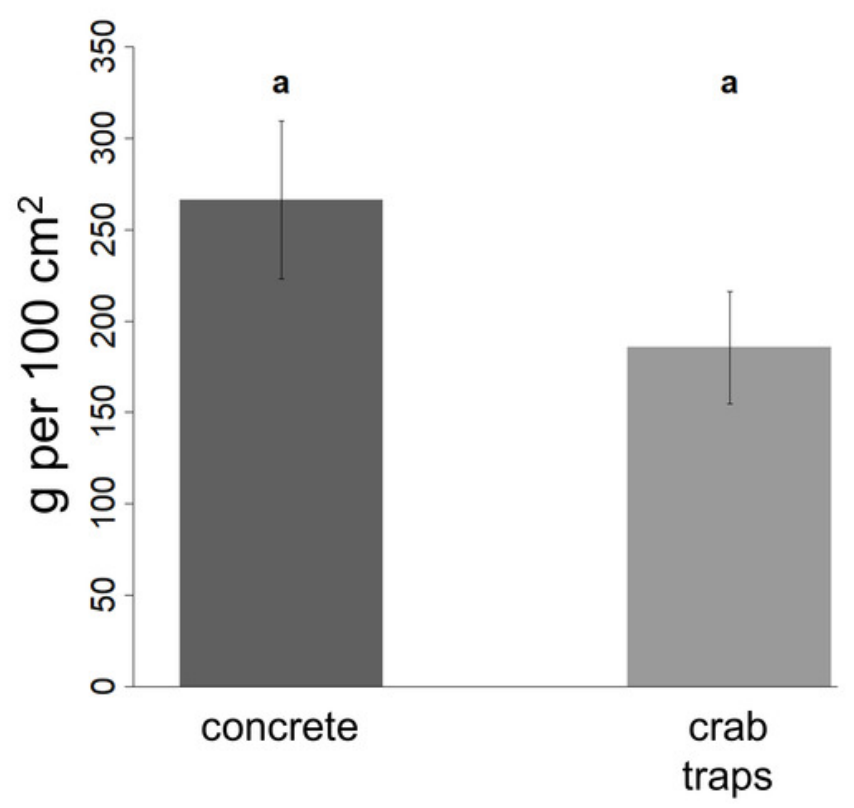




\section{Table 1 (on next page)}

Hypothesis test results for oyster cover and barnacle cover over time. 
1 Table 1. Hypothesis test results for oyster cover and barnacle cover over time.

\begin{tabular}{lrrrc}
\hline Regressor & Estimate & $S E$ & $P$ & $p$-value \\
\hline Oyster cover as response & & & & \\
(intercept) & 2.89 & 1.06 & & 0.007 \\
substrate type (concrete) & 3.23 & $\mathbf{0 . 2 1}$ & $\mathbf{0 . 9 6 2}$ & $<\mathbf{0 . 0 0 1}$ \\
barnacle cover & -0.40 & 0.44 & 0.401 & 0.359 \\
elevation & $\mathbf{- 3 . 9 0}$ & $\mathbf{0 . 9 4}$ & $\mathbf{0 . 0 2 0}$ & $<\mathbf{0 . 0 0 1}$ \\
substrate type (concrete) * barnacle & $\mathbf{- 3 . 2 6}$ & $\mathbf{0 . 4 8}$ & $\mathbf{0 . 0 3 7}$ & $<\mathbf{0 . 0 0 1}$ \\
cover & & & & \\
Barnacle cover as response & & & & $<0.001$ \\
(intercept) & -3.55 & 0.97 & & $<\mathbf{0 . 0 0 1}$ \\
substrate type (concrete) & $\mathbf{1 . 9 1}$ & $\mathbf{0 . 2 1}$ & $\mathbf{0 . 8 7 1}$ & $<\mathbf{0 . 0 0 1}$ \\
oyster cover & $\mathbf{- 1 . 5 6}$ & $\mathbf{0 . 4 1}$ & $\mathbf{0 . 1 7 4}$ & $<\mathbf{0 . 0 0 1}$ \\
elevation & $\mathbf{3 . 4 7}$ & $\mathbf{0 . 9 2}$ & $\mathbf{0 . 9 7 0}$ & $<\mathbf{0 . 0 0 1}$ \\
substrate type (concrete) * oyster cover & $\mathbf{- 3 . 0 9}$ & $\mathbf{0 . 4 3}$ & $\mathbf{0 . 0 4 3}$ &
\end{tabular}

2 Note: Coefficient estimates are log-odds ratios. $P$ is the probability of an increase in the response

3 variable given a unit increase in the regressor. Negative estimates are associated with low

4 probabilities, indicating high probabilities $(1-P)$ of negative effects on the response. Significant

5 fixed effects $(\alpha=0.05)$ are indicated in bold.

6

7

8 


\section{Table 2 (on next page)}

Oyster abundance, biomass, and reef volume statistical summary

Hypothesis test results for oyster abundance, biomass, and reef volume on the final observation date. 
1 Table 2. Hypothesis test results for oyster abundance, biomass, and reef volume on the final 2 observation date.

\begin{tabular}{lrrr}
\hline Regressor & Estimate & $S E$ & $p$-value \\
\hline Spat density (individuals per $100 \mathrm{~cm}^{2}$ ) as response & & & \\
(intercept) & 0.45 & 0.47 & 0.343 \\
substrate type (concrete) & $\mathbf{5 . 0 9}$ & $\mathbf{0 . 6 7}$ & $<\mathbf{0 . 0 0 1}$ \\
barnacle cover & 1.28 & 2.47 & 0.606 \\
substrate type (concrete) * barnacle cover & $\mathbf{- 6 . 6 9}$ & $\mathbf{3 . 2 8}$ & $\mathbf{0 . 0 4 4}$ \\
Juvenile oyster density (individuals per $100 \mathrm{~cm}^{2}$ ) as response & & \\
(intercept) & 14.92 & 6.60 & 0.026 \\
substrate type (concrete) & $\mathbf{9 . 7 2}$ & $\mathbf{1 . 0 9}$ & $<\mathbf{0 . 0 0 1}$ \\
barnacle cover & 4.97 & 3.99 & 0.215 \\
elevation & -10.74 & 6.36 & 0.094 \\
substrate type (concrete) * barnacle cover & $\mathbf{- 1 9 . 7 9}$ & $\mathbf{5 . 3 5}$ & $<\mathbf{0 . 0 0 1}$ \\
Market-size oyster density (individuals per $100 \mathrm{~cm}^{2}$ ) as response & \\
(intercept) & 0.82 & 0.90 & 0.361 \\
substrate type (concrete) & 0.15 & 0.12 & 0.208 \\
elevation & -0.60 & 0.87 & 0.493
\end{tabular}

Total oyster density (individuals per $100 \mathrm{~cm}^{2}$ ) as response

$\begin{array}{lrrr}\text { (intercept) } & 17.27 & 8.25 & 0.038 \\ \text { substrate type (concrete) } & \mathbf{1 5 . 1 1} & \mathbf{1 . 3 7} & <\mathbf{0 . 0 0 1} \\ \text { barnacle cover } & 6.54 & 4.99 & 0.192 \\ \text { elevation } & -12.44 & 7.94 & 0.120 \\ \text { substrate type (concrete) * barnacle cover } & \mathbf{- 2 7 . 2 5} & \mathbf{6 . 6 8} & <\mathbf{0 . 0 0 1} \\ \text { Oyster biomass (g per } 100 \text { cm }^{2} \text { ) as response } & & & \\ \quad \text { (intercept) } & 185.47 & 37.42 & <0.001 \\ \text { substrate type (concrete) } & 80.64 & 52.92 & 0.139 \\ \begin{array}{l}\text { Oyster reef volume (percent change) as response } \\ \text { (intercept) }\end{array} & 234.78 & 56.53 & 0.004 \\ \text { substrate type (concrete) } & \mathbf{- 1 7 . 8 4} & \mathbf{7 . 3 1} & \mathbf{0 . 0 4 5} \\ \text { elevation } & \mathbf{- 1 8 3 . 4 4} & \mathbf{5 4 . 9 2} & \mathbf{0 . 0 1 2}\end{array}$

